\title{
T HE
}

\section{AMERICAN LAW REGISTER.}

FEBRUARY, 1888.

\section{A FEW THOUGHTS ON THE RELATION OF THE COURTS AND THE LAW SCHOOLS TO LEGAL EDUCATION.}

Is the general hurry which has possessed, as it were with a demon, the entire American world, the anxious haste to get on, irrespective of, or with but little respect to, the method of getting on, has infected that profession whose members were, at one time at least, the representatives of gravity and of the idea of a steady approach to an exalted position, of the idea of a long and laborious preparation for great things-and now we find the period of studentship for the bar in most of the United States very much shorter than it used to be, even within the recollection of men by no means old, and as a result the admission to the bar of men scantily prepared for the work of their profession and in many cases riot even so sufficiently equipped as to be able to acquire that learning which in many cases is necessarily postponed until after the technically called studentship has come to an end, not understanding thoroughly the foundations of the law. It is not necessary in order to find a different state of things to go back to the days of laborious preparations of the old English bar-to the long apprenticeship of the Inns-to the dry discipline of pleading under the bar, before receiving a formal call, undergone by so many men whose names will live among us forever ; or, indeed, to cross the water at all ; any one educated in the office, and under the preceptorship of a member of the bar of the old school, will, without trouble, recoguize the

Vor. XXXVI.-10 
difference between the equipment of a young lawyer a few years back, and that of many of those coming to the bar now-between the man who had real and studied the legal classics, and one to whom Coke, even, is too often a book written in a strange tongue. In the old time three years, in some places more, constituted the period of studentship, now tro years is the tcrm in most places, and in some, by means which appear later, a young man can be admitted after even less time of nominal study. The natural result is that in many cases, instead of a serious, earnest, well-prepared lawyer, habituated to labor, to thought, and to waiting, ambitious, indeed, but not desiring to take prematurely a position, failure in which would impair future usefulness, we have a sharp, active practitioner, hurrying to "get business," to get rich, successful often for awhile, but finding his true level before his days are run out. Where is the reason of this not very gratifying result to be sought? In the law schools, which have taken a place which under the American system of legal education they were never intended to take-or, rather, which have assumed to do that which they do not accomplish. In the old American system of legal education the centre of instruction was the office of the preceptor; he directed the course of reading of his pupils, of whom he never took so large a number that he was unable to give them indivilual attention, points of practice which arose he could explain to them; they worked upon pleadings under his supervision; difficulties were carried to him for elucidation; his certificate was necessary before the student could present himself for examination at the bar; and he also took pains to impress upon his pupils the dignity of their profession, its great public weight, and in many cases set before them an example of the learning and honor which are the distinguishing marks of the true lawyer. Now, loes a law school-I have in mind, of course, law schools in general, there may be exceptions to the rule-fill this place to the student? Let us see what the ordinary law school is. In general it is. a collection of four or five professors, doubtless very learned men, who deliver what are doubtless very valuable lectures, containing much instruction very beneficial to those who are fit to thoroughly understand them. At the end of two years, so called, but in reality two courses of instruction, which may 
embrace, from the beginning of the one to the end of the other, only some twenty months, and include only sixteen months of actual instruction, an examination is held by the professors upon what they have tanght, a diploma is grauted to the successful candidate, and this diploma (through the complaisance of the courts, and their desire to fosier the law schooi) in many if not all parts of the Union, entitles the student, who has complied with rules of court as to registration, to admission to the bar. In other words, the law school, which might be a most useful auxiliary in professional education and to many men is such, assumes to fit a man for practice at the bar by the method and after the course abore indicated. Wherein is it defective? In the first place, no means are adopted to insure that the student who attends the lectures is capable of comprehending them; he may come to them utterly unprepared, and with the remotest knowledge of legal principles, without even the foundation of a good education such as is generally obtainable by an academic or collegiate course, and in schools where there is no division into classes for the purpose of hearing lectures, he may be thrown at ence right into the mildle of the course, and after hearing advanced lectures on equity in his first year, may, in his second, be taught what are estates.

Beginning in medias res is very well in poetry, and it is very pleasint to have Eneas brought in safety to Carthage and hear him there, comfortably ensconced, recite the woes of the fall of Troy, rather than to struggle with him through that disaster, but it is hardly the way to properly imbue the mind with legal lore, to build up a solid edifice of scientific lnowledge. To say that the examinations show the fitness of the student is an errorthis examination is by the professors on what they have tanght, not on the general range of law and, while the law school professes to give a legal education and to fit a man for practice, its faculty could not in its examination well travel outside of its own teachings, it would not be common fairness to do so ; now in the few hours a week given generally to instruction, how can any man cover the entire subject of law so as to lay that broad basis upon which the lawyer is to build? A bright, sharp or even a plodding student can well study the lectures of his professors so as to stand an examination on then without under- 
standing the underlying principles or the course which should have led up to the point of knowledge and attainment represented by the lectures-just as a mathematical student may parrot the binomial formula and work with it without in the least knowing how it was arrived at. A little quiet consideration will, we think, convince any one that in actual preparation the law school, as at present constituted and with its present course of short instruction, does not fulfill the requirements of legal elucation. Of course, there might be well imagined an ideal law school一where an entrance examination is required upon the rudiments of the law, or, failing such, where, before the advanced instruction of the professors is given, the students are subjected to a rudimentary drill, where the examinations during the course are frequent, the professors easy of access for the purpose of explanation. But is there one, or more than one such, in the country?

In another way than that of giving insufficient preparation, after assuming the place of the preceptor, has the law school lowered the educational standard of the bar; it has shortened the period of studentship even for those who do not rely on the school for their legal education. This has come about as follows: to encourage law schools, rules of court, or acts of legislature have made the diplomas of schools, or of certain favored schools, sufficient evidence of fitness on the part of its recipient to be admitted to practice. The diploma, we have seen, can be obtained in a period of two years. It soon seemed to the courts that it was unjust to keep out of practice for a year men who for reasons satisfactory to themselves did not go to a law school while students who had started at the same time with them in the course of legal training, and who, perhaps, knew no more, were allowed to practice; as a result, the period of studentship was shortened so as to allow the student of any kind to present himself for examination by the court or its appointed examiners at the end of two years. From this comes the strange spectacle that at a time when the tendency in most of the learned professions and occupations is toward the requirement of a longer course of preparation than has existed heretofore, the term of preparation for the legal profession has actually been reduced. It hardly seems right or in keeping that while the medical profession is 
struxgling to malse a three years' course a sine qua non to the profession of the healing art, the legal profession has reduced in effect its course to two years. It is to be hoped that a reaction wiil take place, and it in the hope of assisting in such a reaction that this article is written.

Improvement in legal education can be brought about in two ways-first, by the courts; second, by the law school, and still better, by both co-operating. Let the courts, who are responsible morally for the character of their officers, fix inflexibly a three years' rule of studentship, applicable alike to law school student and office student, and let them raise the character of their examinations, not only final but preliminary, where preliminary examinations exist, and where they do not exist establish them and require all students to pass both examinations. This, it would seem, could be easily enough done; there is really no reason which should stay, or should be expected to stay, the hands of the judges in refurms of this character. There is some difficulty when we come to the part to be borne by the law school; nevertheless, the difficulty is not insuperable. Let the law school fix its term at not less than three years, and when the expression three years is used we mean that that should be the term required for the ordinary course of study required of all students who are to receive diplomas ; it should not include any of the post graduate courses of study. Here the objection is made that the professors are, very commonly, compensated either by or in proportion to, the fees received fromstudents, and that, unless there were some immediate tangible (i. e., pecuniary or time-saving advantage) to be gained, many young men who otherwise would come to the law school would stay away, and the revenues of the professors or of the school would fall off. This is probably true, but the argument is worthless except upon the assumption that the professors work for hire only and are willing to sacrifice thoroughness of work to pecuniary recompense, and we would be sorry to think so meauly of men sufficiently learned to fill chairs of legal instruction as to think that money was the all in all to them; the laborer is worthy of his hire, beyond all question, and the hire ought to be liberal, but not the man who thinks of his hire only or mainly when the labor is of so farreaching, so important, a character as that of a law professorship. 


\section{6

As to institutions in which the professors are salaried, this objection takes another shape, and it may be said the school cannot exist if attended by so few students. In that case, perhaps the school had better not exist. It is not necessary that there should be a very great number of law schools, and there will always be enough earnest students-men desiring the great aid to be derived from really learned professors-to support a suffcient number of realiy good schools. By increasing its term, especially if the diploma be not permitted to give the right of admission to the bar, the school will hold itself ont no longer as a royal road, or, rather, a short cut, to green pastures of practice, attracting quite as many unworthy as worthy students, but as a place of higher instruction in the science of law, and to carry out this idea it should either insist on an entrance examination on legal rudiments, or it should give to its students a drill therein befure permitting them to attend the lectures of the professors. Ai a result, the school may have fewer students, but it will send out more thoroughly equipped men-it wiil deserve better of the community.

Action of the kind suggestel on the part of the courts and the law school will, we think, remedy that great evil that we hear so much abont-the overcrowding of the profession. The profession is not overcrowded with fit men, but it is overcrowded with men permitted to practice, and every day the distinction between the lawyer and the member of the bar is exemplified; and the distinction is apparent to lawyers, but not to the outsicle world. As a result, we often see the plansible and ignorant man acquiring a practice and an outside reputation, whereby his clients suffer much before his weakness is discovered.

The remedy against such overcrowding is not that which the bar of New York attempted to apply abont the time when John Jay first began the study of the law, namely, refusing to permit young men to pursue the study of the law and to qualify themselves for practice, but by so raising the standard of attainment requisite for admission, that none but fit men shall be permitted to enter upon the practice of the professionraising the standard, that is, to such a height that, while not beyond the reach of the ordinary educated and industrious man, it shall be such that the fact that it has been passed will carry 